\title{
An investigation into the influences of species and biotype on the type of IgA1 protease produced by isolates of Haemophilus
}

\author{
B. W. SENIOR and C. L. IP \\ Department of Medical Microbiology, Dundee University Medical School, Ninewells Hospital, Dundee \\ DD1 9SY
}

\begin{abstract}
A total of 59 isolates of different Haemophilus spp., mostly from clinical specimens, was characterised, biotyped and examined for production of type 1 or type 2 IgA1 protease. IgA1 protease activity was not found in any isolate of a species with no or low virulence for man including $H$. parainfluenzae, $H$. haemolyticus, $H$. aphrophilus, $H$. paraphrophilus, H. segnis, H. paraphrohaemolyticus and $H$. haemoglobinophilus. IgA1 protease was produced by all isolates of $H$. influenzae and $H$. aegyptius and by some isolates of $H$. parahaemolyticus. The type of IgA1 protease appeared to be independent of the biotype of the isolate in $H$. influenzae. For the first time some isolates of $H$. aegyptius were found that produced type 2 IgA1 protease. IgA1 protease production in $H$. parahaemolyticus may be associated with the virulence of the isolate.
\end{abstract}

\section{Introduction}

The mucosal surfaces of the body are protected from damage by micro-organisms and their products principally by the specific immunity provided by immunoglobulin A (IgA) in its secretory form ( $\operatorname{IgA})$. sIga neutralises toxins, enzymes and viruses, agglutinates bacteria and prevents bacterial adhesion to mucous membranes [1-4]. The ability of sIga to perform its defensive effector functions depends upon its structural integrity. The physicochemical nature of sIga renders it resistant to most types of proteolytic attack [5]. However, a few pathogenic bacteria that cause infections at mucous membranes are able to destroy its effector functions through the production of enzymes called IgAl proteases [6-8]. They are so named because they cleave the $\alpha$ chain of $\operatorname{IgAl}$ only and not that of the $\operatorname{IgA} 2$ isotype. These enzymes may be important virulence factors because they are produced in vivo $[9,10]$, patients convalescing from infections with IgA1 protease-producing bacteria have neutralising antibodies to the enzymes [11-13], and related but non-pathogenic bacteria do not produce them [7]. Most strains of Haemophilus influenzae produce serine-type IgA 1 proteases that cleave the $\alpha$ chain in the hinge region at either $\mathrm{Pro}^{231}-\mathrm{Ser}^{232}$ (type 1 enzyme) or Pro $^{235}-\mathrm{Thr}^{236}$ (type 2 enzyme) $[14,15]$. The purpose of

Received 29 June 1998; accepted 21 August 1998.

Corresponding author: Dr B. W. Senior. this study was to examine IgAl protease production among isolates of a wide range of Haemophilus spp. and determine whether or not there was any correlation between the type of enzyme formed and the species and biotype of the strain.

\section{Materials and methods}

\section{Haemophilus strains and their isolation}

Most (52 of 59) of the Haemophilus isolates studied were from clinical specimens. The majority $(22,42 \%)$ were from sputum, seven $(13 \%)$ were from throat swabs and five $(10 \%)$ were from eye swabs. The remainder $(18,35 \%)$ were from nasal and perinasal swabs, ear swabs, endotracheal aspirates and bronchial washings. The specimens were plated out for single colonies on cooked blood agar (CBA) plates and incubated overnight at $37^{\circ} \mathrm{C}$ in air with $\mathrm{CO}_{2} 5 \%$. Half of a well-isolated colony was picked and plated out on Columbia Agar (Oxoid CM 331). The other half of the colony was plated out on CBA. After incubation overnight at $37^{\circ} \mathrm{C}$ in air with $\mathrm{CO}_{2} 5 \%$, those strains that failed to grow on Columbia agar but grew on CBA and which were subsequently shown to be gramnegative short bacilli were saved as probable Haemophilus spp. Haemolytic species of Haemophilus were isolated differently. Blood agar (Blood Agar Base 'Oxoid CM 55' supplemented with horse blood 5\%) plates (BA) were inoculated with swabs from patients with sore throats and incubated anaerobically overnight 
at $37^{\circ} \mathrm{C}$. Well-isolated haemolytic colonies were picked, re-plated on $\mathrm{BA}$ and $\mathrm{V}$-factor growth disks were applied. After incubation overnight at $37^{\circ} \mathrm{C}$ in air with $\mathrm{CO}_{2} 5 \%$, isolates that gave haemolytic colonies whose size was increased by $\mathrm{V}$ factor and were gram-negative short bacilli were saved.

Single isolates of $H$. haemolyticus, $H$. parahaemolyticus, H. aphrophilus, H. paraphrophilus, H. segnis, H. paraphrohaemolyticus and $H$. haemoglobinophilus were purchased from the Haemophilus Reference Laboratory, Oxford Public Health Laboratory. The Haemophilus strains for daily use were maintained as pure cultures on CBA plates at room temperature and subcultured every 3-4 days. Permanent stocks were maintained in Tryptone Soya Broth (Oxoid CM 129) containing glycerol $15 \%$ at $-70^{\circ} \mathrm{C}$.

\section{Media}

Sugar fermentation test medium. Columbia agar (Oxoid CM 331) $3.9 \mathrm{~g}$ and phenol red dye $25 \mathrm{mg}$ were added to $100 \mathrm{ml}$ of distilled water and sterilised by autoclaving at $121^{\circ} \mathrm{C}$ for $15 \mathrm{~min}$. While still molten but cool, the medium was supplemented with both the appropriate sugar (1\%) from a filtered sterile $10 \%$ stock solution and also nicotinamide-adenine dinucleotide (NAD) and haemin (both $10 \mu \mathrm{g} / \mathrm{ml}$ ) were added from sterile stock solutions of each $(10 \mathrm{mg} / \mathrm{ml})$. The complete medium was dispensed aseptically into the wells of a microtitration plate.

Ornithine decarboxylase medium. Bactopeptone (Difco) $0.5 \mathrm{~g}$, yeast extract (Oxoid L21) $0.3 \mathrm{~g}$, glucose, $0.1 \mathrm{~g}$ and phenol-red dye $25 \mathrm{mg}$ were dissolved in $100 \mathrm{ml}$ of distilled water and divided into two portions of $50 \mathrm{ml}$. L-Ornithine $0.5 \mathrm{~g}$ was added to one of these; the other served as the base control. Both were autoclaved at $121^{\circ} \mathrm{C}$ for $15 \mathrm{~min}$ and dispensed aseptically in small volumes into small sterile test tubes.

Indole test medium. This was tryptophan $0.1 \%$ in $50 \mathrm{mM}$ sodium phosphate buffer, $\mathrm{pH} 8$, sterilised by autoclaving at $121^{\circ} \mathrm{C}$ for $15 \mathrm{~min}$.

Urease test medium. Phenol red dye $(0.5 \mathrm{ml}$ of $2 \%)$ was added to $100 \mathrm{ml}$ distilled water in which $\mathrm{K}_{2} \mathrm{HPO}_{4}$ $0.1 \mathrm{~g}, \mathrm{KH}_{2} \mathrm{PO}_{4} \quad 0.1 \mathrm{~g}$ and $\mathrm{NaCl} 0.5 \mathrm{~g}$ had been dissolved and the $\mathrm{pH}$ of the solution was adjusted to 7. After autoclaving at $121^{\circ} \mathrm{C}$ for $15 \mathrm{~min}$ and when cool, the medium was supplemented aseptically with urea $(2 \%)$ from a filtered sterile stock urea solution $(40 \%$ in water).

\section{Speciation and biotyping of strains}

$X$ and $V$ growth factor requirement test. A suspension of the bacterial strain in saline was prepared with a swab from growth on a CBA plate and the same swab was used to streak the suspension across a Columbia agar plate. $\mathrm{X}$ and $\mathrm{V}$ growth factor disks (Mast Diagnostics, Merseyside) were placed over the inoculum and c. $2.5 \mathrm{~cm}$ apart. After incubation overnight at $37^{\circ} \mathrm{C}$ in air with $\mathrm{CO}_{2} 5 \%$, the growth factor requirement of the strain was deduced from the areas in which it had grown.

ALA test. This test determined the ability of a strain to synthesise porphyrins from $\delta$-aminolaevulinic acid (ALA). Strains were inoculated on to ALA discs (Mast Diagnostics) on a Columbia agar plate. After incubation overnight at $37^{\circ} \mathrm{C}$ in air with $\mathrm{CO}_{2} 5 \%$, the plate was examined under UV light. A brick-red fluorescence of the ALA disk indicated porphyrin synthesis from ALA.

Biotyping. All isolates were examined for their ability to form urease, indole and ornithine decarboxylase. The urea, indole and ornithine decarboxylase and base test media were inoculated with two drops of a dense suspension in saline of each strain from a CBA plate. The ornithine decarboxylase and base test media were then overlayered with sterile mineral oil. The reactions were read after incubation for $4 \mathrm{~h}$ at $37^{\circ} \mathrm{C}$ and the addition of Kovac's reagent to the indole test medium. Control strains giving appropriate positive and negative reactions were included in each batch of tests.

\section{Preparation of $\operatorname{Ig} A$ protease}

Sterile dialysis tubing membrane on the surface of a CBA plate was inoculated by swab with an isolate. After incubation for $72 \mathrm{~h}$ at $37^{\circ} \mathrm{C}$ in air with $\mathrm{CO}_{2} 5 \%$, the membrane was removed and the growth from it was

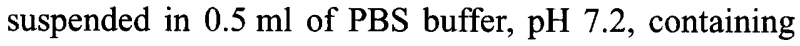
sodium azide $0.1 \%$. The membrane surface was then rinsed in a further $0.5 \mathrm{ml}$ of the buffer and the rinse was combined with the cell suspension. This was centrifuged at $12600 \mathrm{~g}$ for $2 \mathrm{~min}$. The supernate which contained any protease activity was removed and stored at $-20^{\circ} \mathrm{C}$.

\section{Preparation of $\operatorname{Ig} A 1$}

CHO-K1 cells were grown by standard methods. These were Chinese hamster ovary cells bearing mouse genes for the immunoglobulin $\lambda$ chain to the hapten NIP (3nitro-4-hydroxy-5-iodophenylacetate) which had been transfected with the plasmid pJW6 which bears a mouse gene for the variable region of $\alpha$ chain to NIP and human genes for the $\mathrm{CH} 1, \mathrm{CH} 2$ and $\mathrm{CH} 3$ regions of human $\alpha 1$ chain [16]. The culture supernate was incubated overnight at $4^{\circ} \mathrm{C}$ with NIP-coated Sepharose beads. The beads were collected by filtration and, after thorough washing, recombinant IgA1 was eluted from the beads by competition with $1 \mathrm{mM}$ NIP. The IgAl was dialysed thoroughly against PBS containing sodium azide $0.1 \%$ and stored at $-20^{\circ} \mathrm{C}$. 


\section{Characterisation of IgAl protease activity}

Appropriate small volumes of recombinant $\operatorname{IgAl}$ and IgA protease preparations were added to PBS, $\mathrm{pH} 7.2$, containing sodium azide $0.1 \%$ to give a total volume of $15 \mu \mathrm{l}$ and incubated for $72 \mathrm{~h}$ at $37^{\circ} \mathrm{C}$ in a thermal cycler with a heated lid. After the addition of $15 \mu \mathrm{l}$ of $40 \mathrm{mM}$ iodoacetamide in disruption buffer $(8 \mathrm{M}$ urea, SDS $2 \%$, glycerol $20 \%$ and a trace of bromophenol blue dye in $125 \mathrm{mM}$ Tris-HCl buffer, $\mathrm{pH}$ 6.8) and boiling for $5 \mathrm{~min}$, the samples were loaded on to a stacking gel of acrylamide $4.5 \%$ in $125 \mathrm{mM}$ Tris- $\mathrm{HCl}$, $\mathrm{pH} 6.8$, containing SDS $0.1 \%$ over a separating gel of acrylamide $10 \%$ in $375 \mathrm{mM}$ Tris- $\mathrm{HCl}$, $\mathrm{pH} 8.8$, containing SDS $0.1 \%$ and electrophoresed at $150 \mathrm{~V}$ in electrophoresis buffer $(25 \mathrm{~mm}$ Tris, $192 \mathrm{~mm}$ glycine, SDS $0.1 \% \mathrm{pH} 8.3$ ) until the dye front reached the bottom of the gel. The proteins were then transferred to a nitrocellulose membrane by electrophoresis for $1 \mathrm{~h}$ at $100 \mathrm{~V}$ in transfer buffer $(25 \mathrm{~mm}$ Tris, $192 \mathrm{mM}$ glycine in methanol $20 \%$ in water). The membrane was then blocked by agitation for $30 \mathrm{~min}$ in non-fat dried milk protein (Marvel) 5\% in PBS. After thorough washing in PBS, the membrane was immersed in horseradish peroxidase-labelled sheep antibody to human $\alpha$ chain diluted 1 in 1000 in PBS containing Tween $200.1 \%$ and agitated for $2 \mathrm{~h}$ at room temperature. After thorough washing in PBS, the immunoblot was devel- oped in $10 \mathrm{ml}$ of $50 \mathrm{mM}$ Tris- $\mathrm{HCl}, \mathrm{pH} \mathrm{7.6,} \mathrm{containing}$ nickel chloride $3 \mathrm{mg}$, diaminobenzidine $10 \mathrm{mg}$ and hydrogen peroxide $30 \% 60 \mu \mathrm{l}$.

\section{SDS-PAGE of Haemophilus spp.}

Several colonies from isolates grown on CBA were suspended in $1 \mathrm{ml}$ of saline. After centrifugation at $11600 \mathrm{~g}$ for $2 \mathrm{~min}$, the washed cell pellet was resuspended in $100 \mu \mathrm{l}$ of distilled water and $100 \mu \mathrm{l}$ of sample buffer (glycerol 20\%, SDS $4 \%$, mercaptoethanol $10 \%$ and a trace of bromophenol blue dye in $0.125 \mathrm{M}$ Tris- $\mathrm{HCl}$ buffer, $\mathrm{pH} 6.8$ ). After being boiled for $5 \mathrm{~min}$, portions of the preparations were electrophoresed on a polyacrylamide $(10 \%)$ gel and stained as described previously [17].

\section{Results}

The clinical isolates were identified to species according to the criteria in Table 1 and biotyped on the basis of formation of indole, urease and ornithine decarboxylase according to the schemes of Kilian and others [18-21] (Table 2). At this stage, three strains that did not acidify xylose but were otherwise indistinguishable by biotyping from $H$. influenzae strains of biotype 3 , were called $H$. aegyptius. These species were differ-

Table 1. Biochemical characteristics of the clinical isolates of Haemophilus spp.

\begin{tabular}{llcccc}
\hline Species & $\begin{array}{l}\text { Growth factor } \\
\text { requirement }\end{array}$ & ALA test ${ }^{*}$ Haemolysis $^{\dagger}$ & Xylose $^{\ddagger}$ & Sucrose $^{\ddagger}$ \\
\hline$H$. influenzae & $\mathrm{X}$ and V & - & - & + & - \\
H. parainfluenzae & $\mathrm{V}$ & + & - & - & + \\
H. aegyptius & $\mathrm{X}$ and V & - & - & + & - \\
H. haemolyticus & $\mathrm{X}$ and V & - & + & - & - \\
$H$. parahaemolyticus & $\mathrm{V}$ & + & + & - & + \\
\hline${ }^{*}$ Synthesis of porphyrins from $\delta$-aminolaevulinic acid. & & & \\
${ }^{\dagger}$ Haemolysis on horse blood agar plates. & & & \\
${ }^{\ddagger}$ Acidification of sugar.
\end{tabular}

Table 2. The types of $\operatorname{IgAl}$ protease produced by different species and biotypes of Haemophilus

\begin{tabular}{|c|c|c|c|c|c|c|c|}
\hline \multirow[b]{2}{*}{ Species } & \multicolumn{3}{|c|}{ Formation of } & \multirow[b]{2}{*}{ Biotype } & \multirow{2}{*}{$\begin{array}{l}\text { Number of } \\
\text { isolates }\end{array}$} & \multicolumn{2}{|c|}{$\begin{array}{l}\text { Number }(\%) \text { producing } \operatorname{IgA} 1 \\
\text { protease of }\end{array}$} \\
\hline & Indole & Urease & ODC & & & type 1 & type 2 \\
\hline \multirow[t]{5}{*}{ H. influenzae } & + & + & + & 1 & 7 & $2(28.5)$ & $5(71.5)$ \\
\hline & + & + & - & 2 & 21 & $11(52)^{*}$ & $9(43)^{*}$ \\
\hline & - & + & - & 3 & 7 & $2(28.6)$ & $5(71.4)$ \\
\hline & - & + & + & 4 & 2 & $2(100)$ & $0(0)$ \\
\hline & + & - & - & 7 & 1 & $1(100)$ & $0(0)$ \\
\hline \multirow[t]{4}{*}{ H. parainfluenzae } & - & + & + & 2 & 2 & $0(0)$ & $0(0)$ \\
\hline & - & + & - & 3 & 2 & $0(0)$ & $0(0)$ \\
\hline & + & + & + & 4 & 1 & $0(0)$ & $0(0)$ \\
\hline & + & + & - & 7 & 2 & $0(0)$ & $0(0)$ \\
\hline H. aegyptius & - & + & - & - & 3 & $1(33)$ & $2(66)$ \\
\hline H. haemolyticus & - & + & - & - & 3 & $0(0)$ & $0(0)$ \\
\hline H. parahaemolyticus & $\mathrm{V}$ & + & $\mathrm{V}$ & - & 3 & $0(0)$ & $1(33)$ \\
\hline H. aphrophilus & NT & NT & NT & - & 1 & $0(0)$ & $0(0)$ \\
\hline H. paraphrophilus & NT & NT & NT & - & 1 & $0(0)$ & $0(0)$ \\
\hline H. segnis & NT & NT & NT & - & 1 & $0(0)$ & $0(0)$ \\
\hline H. paraphrohaemolyticus & NT & NT & NT & - & 1 & $0(0)$ & $0(0)$ \\
\hline H. haemoglobinophilus & NT & NT & NT & - & 1 & $0(0)$ & $0(0)$ \\
\hline
\end{tabular}

ODC, ornithine decarboxylase; NT, not tested; V, different isolates gave different results.

* One isolate produced both type 1 and type 2 enzyme. 
entiated by SDS-PAGE of the major proteins of the three xylose-negative strains with seven $H$. influenzae biotype 3 strains as controls. The profiles of the $H$. influenzae strains were all very similar and had as major bands proteins of $39,37.5$ and $36.5 \mathrm{kDa}$ (Fig. 1). However, those of the three xylose-negative strains were distinct from these and from one another. The most obvious differences, among others, in the xylosenegative strains were that strain 3 had major proteins of $39,36.5$ and $35.5 \mathrm{kDa}$, strain 5 had major proteins of $39,38.5$ and $34.5 \mathrm{kDa}$ and strain 38 had major proteins of 37 and $35.5 \mathrm{kDa}$. It was concluded that the three xylose-negative strains were indeed strains of $H$. aegyptius.

As shown in Table 2, $H$. influenzae was the species most frequently isolated and comprised 38 (73\%) of the 52 clinical isolates studied. $H$. influenzae biotype 2 strains were the most commonly encountered biotype ( 21 isolates, $55 \%$ of the total $H$. influenzae isolates), followed by biotypes 1 and 3 (seven isolates each, 18.4\%). Strains of biotypes 4 and 7 were encountered less frequently. There was no obvious correlation between the biotype of the strain and the clinical specimen from which it was isolated.

Other species of Haemophilus were isolated less commonly. Among these were $H$. parainfluenzae (seven isolates), H. aegyptius (three), H. haemolyticus (two) and $H$. parahaemolyticus (two).

All the clinical isolates, together with the strains from the reference laboratory (a total of 59 isolates of 10 species of Haemophilus), were examined for IgA1 protease production. IgAl protease activity was detected on immunoblots of non-reduced samples as a protein band of either $53 \mathrm{kDa}$ or $51.5 \mathrm{kDa}$ representing the action, respectively, of a type 2 or a type $1 \mathrm{IgA} 1$ protease (Fig. 2). The bands were the Fab fragments formed by cleavage of the $\alpha$ chain at either Pro $^{231}-\mathrm{Ser}^{232}$ (type 1 enzyme) or $\mathrm{Pro}^{235}-\mathrm{Thr}^{236}$ (type 2 enzyme). The results of IgAl protease production and the type of enzyme formed are presented in Table 2. From this it can be seen that IgA protease production was characteristic of all isolates of $H$. influenzae, regardless of their biotype, and was found in all $H$. aegyptius and one of three strains of $H$. parahaemolyticus. IgA protease production was not detected in any of the other Haemophilus spp. associated with man nor in $H$. haemoglobinophilus, whose natural host is the dog. Although all of the few isolates of $H$. influenzae of biotypes 4 and 7 produced only type 1 IgA protease, among the more numerous isolates of $H$. influenzae of biotypes 1,2 and 3 , isolates were found that formed either type 1 or type $2 \operatorname{IgA}$ protease. In one case an isolate of $H$. influenzae of
1
2
34
5
6
7
8
9
10

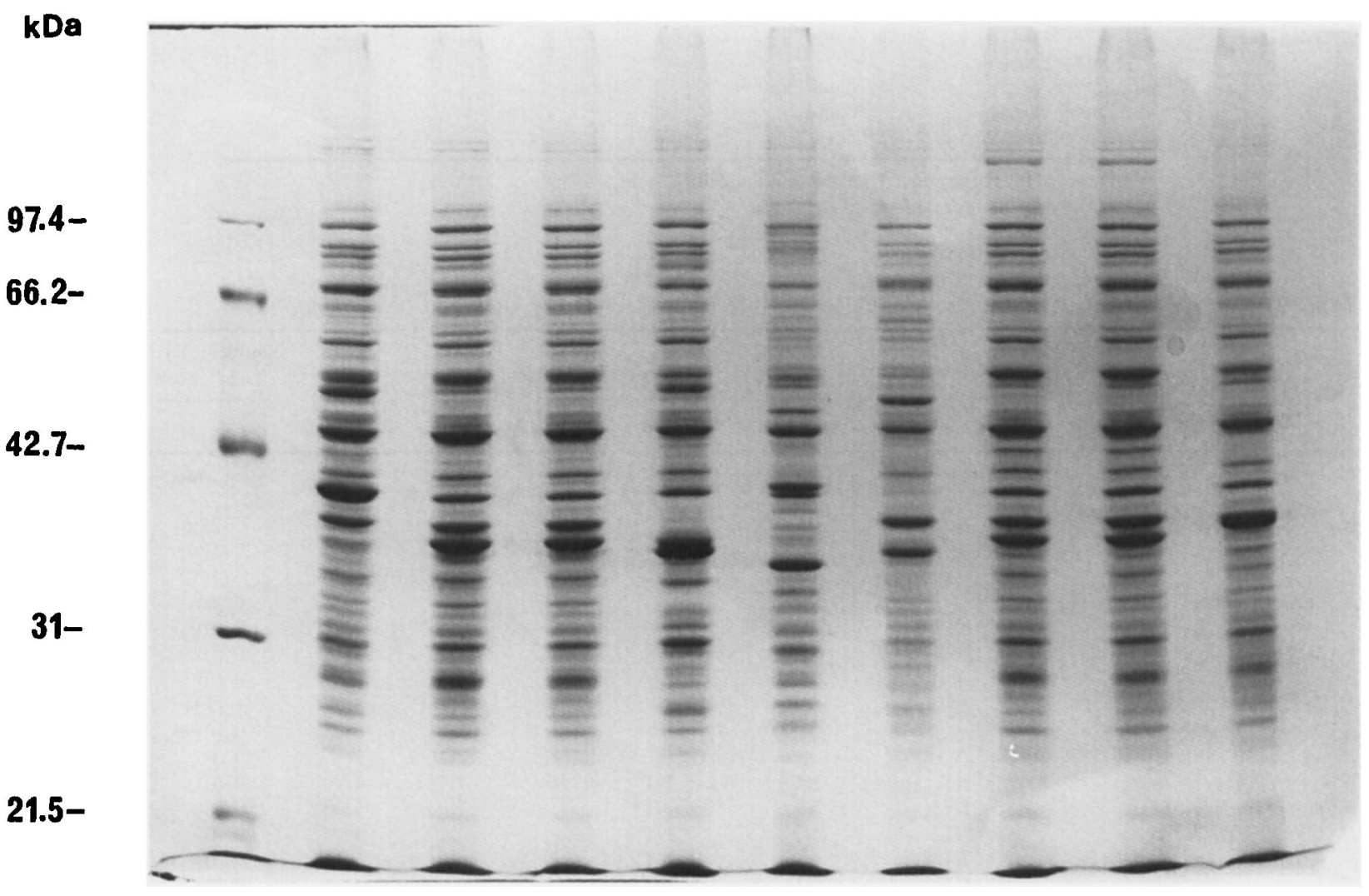

Fig. 1. SDS-PAGE of the major proteins of $H$. influenzae biotype 3 isolates: Lane 1, mol. wt protein standards; 2, isolate $20 ; 3,22 ; 4,24 ; 8,26 ; 9,28 ; 10,43$ and xylose-negative $H$. aegyptius isolates; 5 , isolate $3,6,5 ; 7,38$. 


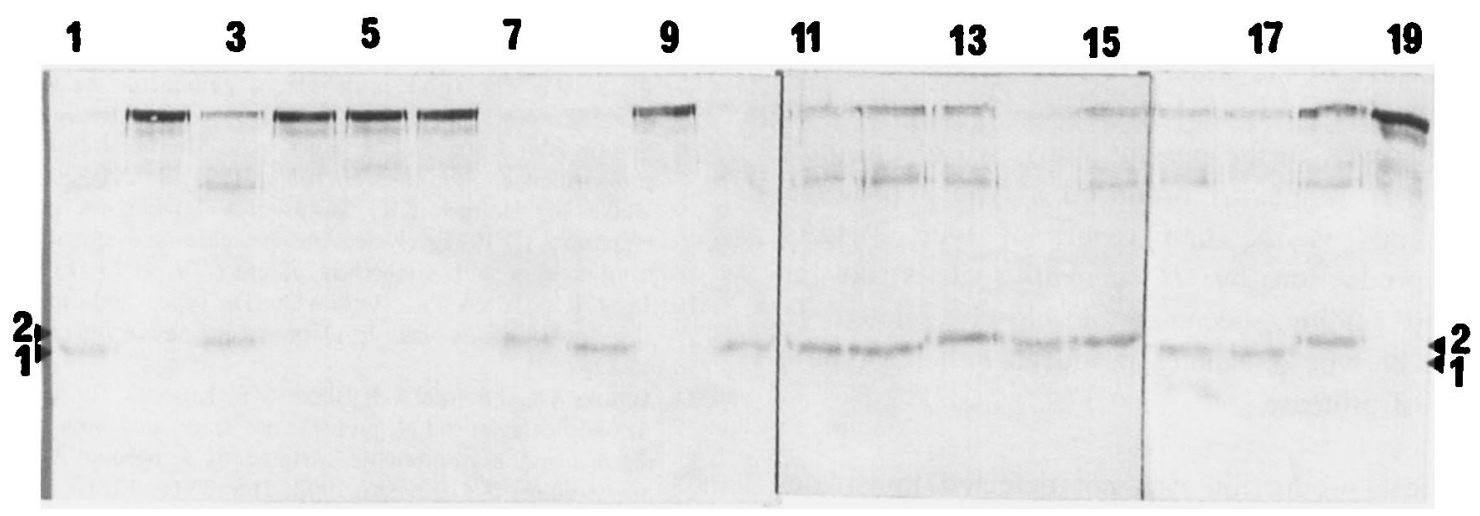

Fig. 2. Immunoblot of recombinant IgA1 after incubation with preparations from Haemophilus spp. and electrophoresis under non-reducing conditions showing Fab fragments produced by type 1 and type 2 IgAl protease. Preparations and enzyme type were lane $1, H$. influenzae biotype 1 , isolate 27 , type $1 ; 2$, IgA1 control, no enzyme; 3, H. influenzae biotype 1 , isolate 4 , type $2 ; 4, H$. parainfluenzae biotype 2 , isolate $7 ; \mathbf{5}, H$. aphrophilus; $6, H$. paraphrophilus; $7, H$. influenzae biotype 2 , isolate 9 , type $2 ; \mathbf{8}, H$. influenzae biotype 2 , isolate 6 , type $1 ; 9, H$. haemolyticus; 10, H. influenzae biotype 3 , isolate 20 , type $1 ; 11, H$. influenzae biotype 4 , isolate 41 , type $1 ; 12$, H. aegyptius isolate 3 , type $1 ; 13, H$. aegyptius isolate 5 , type $2 ; 14, H$. influenzae biotype 3 , isolate 22 , type $2 ; 15, H$. parahaemolyticus isolate 50 , type $2 ; 16, H$. influenzae biotype 7 , isolate 25 , type $1 ; 17, H$. influenzae biotype 2 , isolate 31, type $1 ; 18, H$. influenzae biotype 2 , isolate 33 , type $2 ; 19, H$. segnis.

biotype 2 formed both enzymes simultaneously. When the biotype of the isolate was disregarded, almost exactly the same number of $H$. influenzae isolates formed type 1 protease as formed the type 2 enzyme. Thus, it appeared that, in $H$. influenzae, the biotype of the strain probably had no influence on the type of IgAl protease formed.

One of the three $H$. aegyptius isolates produced a type 1 IgA1 protease and two produced a type 2 enzyme (Fig. 2). This is believed to be the first recorded detection of type $2 \operatorname{IgA} 1$ protease production by $H$. aegyptius. One of the three isolates of $H$. parahaemolyticus produced IgA1 protease of type 2 .

\section{Discussion}

H. influenzae is a major pathogen of man and virtually all isolates - regardless of the presence or absence of capsules, capsule serotype, biotype and origin - have been shown to produce IgA1 protease [22-25]. Indeed, even in the few isolates that do not produce the enzyme, the iga gene sequence can be detected in the genome [26]. The results presented here, which showed that all the isolates of $H$. influenzae from a variety of sources whose capsulate state and type were unknown produced IgAl protease, substantiate this fact. Most strains form a type 1 or a type 2 enzyme, but occasionally a strain is found that produces both types of protease simultaneously [14]. Although non-capsulate strains of $H$. influenzae produce IgA1 protease, there is a strong correlation between the capsular serotype of the strain and the type of enzyme formed. Thus most strains of capsular serotypes A, B and D form type 1 enzyme, those of serotypes $C$ and $E$ form type 2 enyzme [25]. However, although the $H$. influenzae isolates in the present study were not capsule serotyped, the biotyping results suggest that, by way of contrast, there is little or no correlation between $H$. influenzae biotype and the type of enzyme formed. This is in agreement with the findings of Mulks et al. [25]. Both type 1 and type 2 proteases were found to be produced by $H$. influenzae isolates of biotypes 2 and 3 and, although all the $H$. influenzae isolates of biotypes 4 and 7 produced only type 1 protease, there were few isolates of these biotypes; examination of more isolates may have detected some that produced type 2 enzyme. This kind of problem may be the reason why others [25] found all of three strains of $H$. influenzae of biotype 1 to produce type 1 enzyme, whereas among the seven biotype 1 isolates in the present study, two produced type 1 enzyme and five produced type 2 . When the biotype of the $H$. influenzae isolate was disregarded, the numbers of isolates producing type 1 and type 2 enzymes were almost the same.

H. aegyptius is also a known pathogen of man and is associated with conjunctivitis and Brazilian purpuric fever [27]. $H$. aegyptius strains share $>90 \%$ DNA sequence homology with $H$. influenzae [27] and have so many properties in common with $H$. influenzae that many now call them $H$. influenzae biogroup aegyptius. Despite the close similarity between $H$. influenzae biotype 3 strains and $H$. aegyptius strains, the two can be distinguished. The best discriminating test is analysis of their outer-membrane proteins [28]. The SDS-PAGE results in the present study supported the view that the xylose-negative isolates were different from the $H$. influenzae biotype 3 strains and were indeed isolates of $H$. aegyptius. Because of these similarities with $H$. influenzae, it was not surprising to find that all the $H$. aegyptius isolates produced IgA protease. This finding is in agreement with the work of others $[14,29]$. However, all the $H$. aegyptius 
strains so far reported [14] produce a type 1 protease, for they cleave at the same site $\left(\operatorname{Pro}^{231}-\mathrm{Ser}^{232}\right)$ on the $\alpha$ chain as that of type 1 protease of $H$. influenzae strains. However, in the present study two of the three isolates of $H$. aegyptius produced a type 2 protease. Although this is the first report of type $2 \operatorname{IgA} 1$ protease production by $H$. aegyptius it is not an unexpected finding, because the closely related $H$. influenzae biotype 3 isolates produced either a type 1 or a type 2 protease.

IgA protease production was not detected in isolates of $H$. parainfluenzae, $H$. haemolyticus, $H$. aphrophilus, H. paraphrophilus, H. segnis, H. paraphrohaemolyticus or $H$. haemoglobinophilus despite incubation of culture supernates with recombinant IgAl for $72 \mathrm{~h}$. Although for some of these species only single isolates were examined, the results support the findings of others $[22-24,29]$. These species are considered to have low or no pathogenicity for man and this finding gives support to the hypothesis that IgA protease production is a virulence factor for pathogenic species of Haemophilus.

IgA protease production was also detected in one of three isolates of $H$. parahaemolyticus. Others have also reported that a minority of strains of $H$. parahaemolyticus form IgA protease [23, 24, 29]. This organism is commonly found in the oral cavity and pharynx of most healthy people [30] and as such is often regarded as non-pathogenic. However, it is also one of the commonest isolates from purulent infections of the oral cavity [31]. This may indicate that some isolates of this organism may be pathogenic. Kilian [18] has shown that $H$. parahaemolyticus isolates can be separated into two groups on the basis of biochemical reactions. It would be interesting to determine if $\operatorname{IgA}$ protease production is restricted to the isolates from purulent infections and whether or not these have other biochemical activities that distinguish them from the commensal isolates.

\section{References}

1. Kilian M, Russel MW. Function of mucosal immunoglobulins. In: Ogra PL, Mestecky J, Lamm ME, Strober W, McGhee JR, Bienenstock J (eds) Handbook of mucosal immunology. San Diego, Academic Press. 1994: 127-137.

2. Liljemark WF, Bloomquist CG, Ofstehage JC. Aggregation and adherence of Streptococcus sanguis: role of human salivary immunoglobulin A. Infect Immun 1979; 26: 1104-1110.

3. Svanborg-Edén C, Svennerholm A-M. Secretory immunoglobulin $\mathrm{A}$ and $\mathrm{G}$ antibodies prevent adhesion of Escherichia coli to human urinary tract epithelial cells. Infect Immun 1978; 22: $790-797$.

4. Williams RC, Gibbons RJ. Inhibition of bacterial adherence by secretory immunoglobulin A: a mechanism of antigen disposal. Science 1972; 177: 697-699.

5. Lindh E. Increased resistance of immunoglobulin A dimers to proteolytic degradation after binding of secretory component. $J$ Immunol 1975; 114: 284-286.

6. Kilian M, Reinholdt J, Lomholt H, Poulsen K, Frandsen EVG. Biological significance of IgA1 proteases in bacterial coloniza- tion and pathogenesis: critical evaluation of experimental evidence. APMIS 1996; 104: 321-338.

7. Plaut AG. The IgA1 proteases of pathogenic bacteria. Annu Rev Microbiol 1983; 37: 603-622.

8. Senior BW, Loomes LM, Kerr MA. Microbial IgA proteases and virulence. Rev Med Microbiol 1991; 2: 200-207.

9. Blake M, Holmes KK, Swanson J. Studies on gonococcus infection. XVII. IgAl-cleaving protease in vaginal washings from women with gonorrhea. J Infect Dis 1979; 139: 89-92.

10. Insel RA, Allen PZ, Berkowitz ID. Types and frequency of Haemophilus influenzae IgAl proteases. Semin Infect Dis 1982; 4: 225-231.

11. Brooks GF, Lammel CJ, Blake MS, Kusecek B, Achtman M. Antibodies against IgA protease are stimulated both by clinical disease and asymptomatic carriage of serogroup A Neisseria meningitidis. J Infect Dis 1992; 166: 1316-1321.

12. Devenyi AG, Plaut AG, Grundy FJ, Wright A. Post-infectious human serum antibodies inhibit IgA1 proteinases by interaction with the cleavage site specificity determinant. Mol Immunol 1993; 30: $1243-1248$.

13. Gilbert JV, Plaut AG, Longmaid B, Lamm ME. Inhibition of microbial IgA proteases by human secretory IgA and serum. Mol Immunol 1983; 20: 1039-1049.

14. Kilian M, Thomsen B, Petersen ET, Bleeg H. Molecular biology of Haemophilus influenzae $\operatorname{IgAl}$ proteases. Mol Immunol 1983; 20: 1051-1058.

15. Bachovchin WW, Plaut AG, Flentke GR, Lynch M, Kettner CA. Inhibition of IgAl proteinases from Neisseria gonorrhoeae and Haemophilus influenzae by peptide prolyl boronic acids. $J$ Biol Chem 1990; 265: 3738-3742.

16. Morton HC, Atkin JD, Owens RJ, Woof JM. Purification and characterization of chimeric human IgAl and IgA2 expressed in $\operatorname{COS}$ and Chinese hamster ovary cells. J Immunol 1993; 151: 4743-4752.

17. Senior BW, Vörös S. Protein profile typing - a new method of typing Morganella morganii strains. J Med Microbiol 1990; 33: 259-264.

18. Kilian M. A taxonomic study of the genus Haemophilus, with the proposal of a new species. $J$ Gen Microbiol 1976; 93: 9-62.

19. Oberhofer TR, Back AE. Biotypes of Haemophilus encountered in clinical laboratories. J Clin Microbiol 1979; 10: 168-174.

20. Gratten M. Haemophilus influenzae biotype VII. J Clin Microbiol 1983; 18: 1015-1016.

21. Sottnek FO, Albritton WL. Haemophilus influenzae biotype VIII. J Clin Microbiol 1984; 20: 815-816.

22. Kilian M, Mestecky J, Schrohenloher RE. Pathogenic species of the genus Haemophilus and Streptococcus pneumoniae produce immunoglobulin Al protease. Infect Immun 1979; 26: 143-149.

23. Male CJ. Immunoglobulin A1 protease production by Haemophilus influenzae and Streptococcus pneumoniae. Infect Immun 1979; 26: 254-261.

24. Mulks MH, Kornfeld SJ, Plaut AG. Specific proteolysis of human IgA by Streptococcus pneumoniae and Haemophilus influenzae. $J$ Infect Dis 1980; 141: 450-456.

25. Mulks MH, Kornfeld SJ, Frangione B, Plaut AG. Relationship between the specificity of IgA proteases and serotypes in Haemophilus influenzae. J Infect Dis 1982; 146: 266-274.

26. Poulsen K, Hjorth JP, Kilian M. Limited diversity of the immunoglobulin Al protease gene (iga) among Haemophilus influenzae serotype b strains. Infect Immun 1988; 56: 987-992.

27. Brenner DJ, Mayer LW, Carlone GM et al. Biochemical, genetic, and epidemiologic characterization of Haemophilus influenzae biogroup aegyptius (Haemophilus aegyptius) strains associated with Brazilian Purpuric fever. $J$ Clin Microbiol 1988; 26: 1524-1534.

28. Carlone GM, Sottnek FO, Plikyatis BD. Comparison of outer membrane protein and biochemical profiles of Haemophilus aegyptius and Haemophilus influenzae biotype III. $J$ Clin Microbiol 1985; 22: 708-713.

29. Kilian M, Thomsen B, Petersen TE, Bleeg HS. Occurrence and nature of bacterial IgA proteases. Ann NY Acad Sci 1983; 409: 612-623.

30. Sims W. Oral haemophili. J Med Microbiol 1970; 3: 615-625.

31. Sims W, Path MR. The clinical bacteriology of purulent oral infections. Br J Oral Surg 1974; 12: 1-2. 